\title{
REGULATION OF ANTIBIOTIC PRODUCTION: CATABOLITE INHIBITION AND THE DUALISTIC EFFECT OF GLUCOSE ON INDOLMYCIN PRODUCTION
}

\author{
Laurence H. Hurley* and Donald Bialek \\ Department of Pharmacognosy, University of Maryland, \\ School of Pharmacy, 636 W. Lombard Street \\ Baltimore, Maryland 21201, U.S.A.
}

(Received for publication September 25, 1973)

\begin{abstract}
The production of the antibiotic, indolmycin, was shown to be inhibited by glucose at $0.5 \%$. Concentrations of glucose of $0.005 \%$ and $0.01 \%$ produced a stimulation of indolmycin production. Of a selection of mono and disaccharides examined, glucose and to a lesser extent mannose, caused inhibition of indolmycin production. Galactose, fructose and sucrose all caused stimulation of indolmycin synthesis.
\end{abstract}

The antibiotic indolmycin is produced by Stteptomyces griseus (ATCC 12648). This strain was formerly classified as Streptomyces albus ${ }^{11}$. Indolmycin has been shown to have antimicrobial activity against both Gram-negative and Gram-positive microorganisms ${ }^{2 \sim 41}$. The biogenetic origin and partial elucidation of the pathway leading to indolmycin synthesis has been reported by Hornemann, et al. ${ }^{5)}$. These investigators have shown that the antibiotic is largely derived from tryptophan with contributions from methionine (methyl group) and arginine (guanido group).

Catabolite inhibition of antibiotic production by glucose has been demonstrated in a number of instances ${ }^{6 \sim 101}$. In the case of streptomycin and actinomycin, glucose has been shown to repress the formation of enzymes involved in their biosynthesis ${ }^{7,11 \sim 13)}$. We have examined the effect of glucose and other carbon compounds on indolmycin formation and wish to describe our results in the present communication.

\section{Materials and Methods}

Chemicals and Radioisotopes

DL-[Alanine- $\left.3-{ }^{14} \mathrm{C}\right]$ tryptophan $(57 \mathrm{mCi} / \mathrm{mmole})$ was purchased from Amersham $/$ Searle. In all experiments except where otherwise indicated DL-[alanine- $\left.3-{ }^{14} \mathrm{C}\right]$ tryptophan was added to the medium at $0.1 \mu \mathrm{Ci} / 0.1 \mu$ mole per $\mathrm{ml}$ final concentration. Indolmycin was obtained as a gift from U. Hornemann, Purdue University. Other chemicals used were obtained from commercial sources.

Cultivation of the Organism

S. griseus ATCC 12648 was maintained on slants of EMERSON's agar at $24^{\circ} \mathrm{C}$. To prepare a seed culture, spores were transferred aseptically to a 500-ml Erlenmeyer flask containing $100 \mathrm{ml}$ of culture medium, which was incubated for $4 \sim 5$ days at $24^{\circ} \mathrm{C}$ on a Eberbach rotatory shaker. A one milliliter sample of the seed culture was inoculated to a 500-ml Erlenmeyer flask containing $100 \mathrm{ml}$ of the same medium and this was incubated with shaking as before. After

* Present Address: Division of Pharmacognosy and Natural Products, College of Pharmacy, University of Kentucky, Lexington, Kentucky 40506, U.S.A. 
36 hours, one $\mathrm{ml}$ aliquots were used to inoculate the experimental flasks. In all experiments, the culture medium used (g/liter) consisted of polypeptone (BBL), 20.0; yeast extract (BBL), 2.0; $\mathrm{FeSO}_{4} \cdot 7 \mathrm{H}_{2} \mathrm{O}, 0.001$ and a trace element solution $(1 \mathrm{ml} / \mathrm{liter})^{14)}$ in distilled water, $\mathrm{pH} 6.95$.

Radioisotope Feeding Experiments with $S$. griseus

(1) Long-time course experiment. Two series of parallel flasks were used in this experiment. In one series of flasks (designated the test series) 26 hours after inoculation a solution of glucose was added to each flask to produce a final glucose concentration of $0.5 \%$.

At 12-hour intervals, DL-[alanine- $\left.3-{ }^{14} \mathrm{C}\right]$ tryptophan was added aseptically to pairs of flasks. Twelve hours after addition, the flasks were harvested, filtered to remove the mycelium, and the indolmycin was isolated from the medium as previously described ${ }^{51}$. The percentage incorporation of tryptophan into indolmycin was determined as previously described ${ }^{15)}$.

(2) Shorter time course experiment. Three flasks of the $S$. griseus culture were removed from the shaker after 33 hours and pooled. DL-[Alanine- $3-{ }^{14} \mathrm{C}$ ] tryptophan was added and $100 \mathrm{ml}$ aliquots of the culture were placed in two 500-ml Erlenmeyer flasks. To one of these, glucose $(0.5 \%$, final concentration) was added and the flasks were reincubated for 24 hours. At various times, $10 \mathrm{ml}$ aliquots of the cultures were taken and the percentage incorporation of tryptophan into indolmycin was determined.

(3) The effect of glucose concentration and different sugars on indolmycin production. Cultures were removed from the shaker at 33 hours, pooled and DL-[alanine- $\left.3-{ }^{14} \mathrm{C}\right]$ tryptophan at $0.05 \mu \mathrm{Ci} / 0.1 \mu$ mole per $\mathrm{ml}$ fiinal concentration was added. Forty $\mathrm{ml}$ aliquots were transferred to $250-\mathrm{ml}$ Erlenmeyer flasks, the carbon source in question was added and then the cultures were reincubated for 24 hours.

Determination of Mycelial Dry Weight

Cultures were filtered on a Buchner funnel by suction on a tared Whatman \#42 paper $(5.5 \mathrm{~cm})$ discs. After washing with distilled water, filter papers and mycelium were wrapped in paper towels and dried overnight at $105^{\circ} \mathrm{C}$. After standing at room temperature for about $3 \sim 4$ hours to equilibrate, the paper and mycelium was reweighed and the weight of the mycelium determined.

Quantitative Determination of Indolmycin

To the indolmycin isolated from the medium $1 \mathrm{ml}$ of distilled water and $2 \mathrm{ml}$ of VAN URK's reagent $^{15)}$ were added to the residue. After 30 minutes, the optical density at $580 \mu \mathrm{m}$ was measured in a Spectronic 20 spectrophotometer (Bausch and Lomb). The amount of indolmycin in $\mathrm{mg}$ in a sample was determined by comparison with a standard preparation of pure indolmycin. Since the yield of purified indolmycin varied from one isolation to another, it was essential to adjust for the percentage recovery from each isolation. This latter figure was determined by following the amount of recovered radioactive indolmycin through to the end of the isolation procedure.

Quantitative Determination of Glucose

D-Glucose concentration was determined by means of the Glucostat special assay system ${ }^{16)}$. The amount of glucose in other carbon compounds was determined after standing overnight in aqueous solution $(1 \mathrm{~g}$ in $10 \mathrm{ml})$ to allow the mutarotation to reach equilibrium.

Radioactive Measurements

Radioactive measurements were carried out in a Nuclear Chicago Liquid Scintillation Spectrometer. A solution $(10 \mathrm{ml})$ containing $7 \mathrm{~g}$ of PPO and $0.3 \mathrm{~g}$ of dimethyl POPOP in 1 liter of toluene were used as scintillation solution. Radioactivity on chromatograms was detected using a Packard Model 7201 Radiochromatogram Scanner.

\section{Results}

The influence of $0.5 \%$ glucose on the growth of S. griseus is shown in Fig. 1A. The addition of glucose prolonged the period of active growth and resulted in an increase in the weight of mycelium of about $100 \mathrm{mg} / 100 \mathrm{ml}$ of medium. Utilization of added glucose was 
complete within 36 hours after addition.

Glucose almost completely inhibited the incorporation of tryptophan into indolmycin until all the glucose had been utilized. However, the maximum incorporation achieved was lower than the control and the duration over which incorporation of tryptophan into indolmycin occurred was less than the control (Fig. 1B). Finally glucose delayed the phase of most rapid synthesis of indolmycin production until 96 hours. However, the length of time for which maximum production occurred and consequently the final amount of indolmycin produced was less than in the control culture (Fig. 1C).

After a lag period of about 4 hours there is a linear increase in the incorporation of tryptophan into indolmycin in both the control and test flasks (Fig. 2). Glucose at a final concentration of $0.5 \%$ produces a $75 \%$ decrease in the incorporation of tryptophan into indolmycin.

The influence of varying concentrations of glucose on the parameters followed during this experiment is shown in Fig. 3. Glucose at concentration of $0.005 \%$ and $0.01 \%$ produced no increase in the dry weight of mycelium over the two control cultures. At these same low concentrations of glucose there was an increase in percentage incorporation of tryptophan into indolmycin over the control flasks and also an increase in the amount of indolmycin produced during this period over the control. Conversely concentrations of glucose of $0.05 \%$ and higher produced an increase in weight of mycelium produced, a decrease in percentage incorporation of tryptophan
Fig. 1. Effect of glucose $(0.5 \%)$ on, (A) the growth of Streptomyces griseus, on (B) incorporation of DL-[alanine-3- ${ }^{14} \mathrm{C}$ ]tryptophan into indolmycin and on (C) indolmycin biosynthesis.

Glucose was added at 26 hours to the test flasks. Twelve hours prior to harvesting DL[alanine- $3-{ }^{14} \mathrm{C}$ ]tryptophan was added to pairs of flasks from the control and test series.
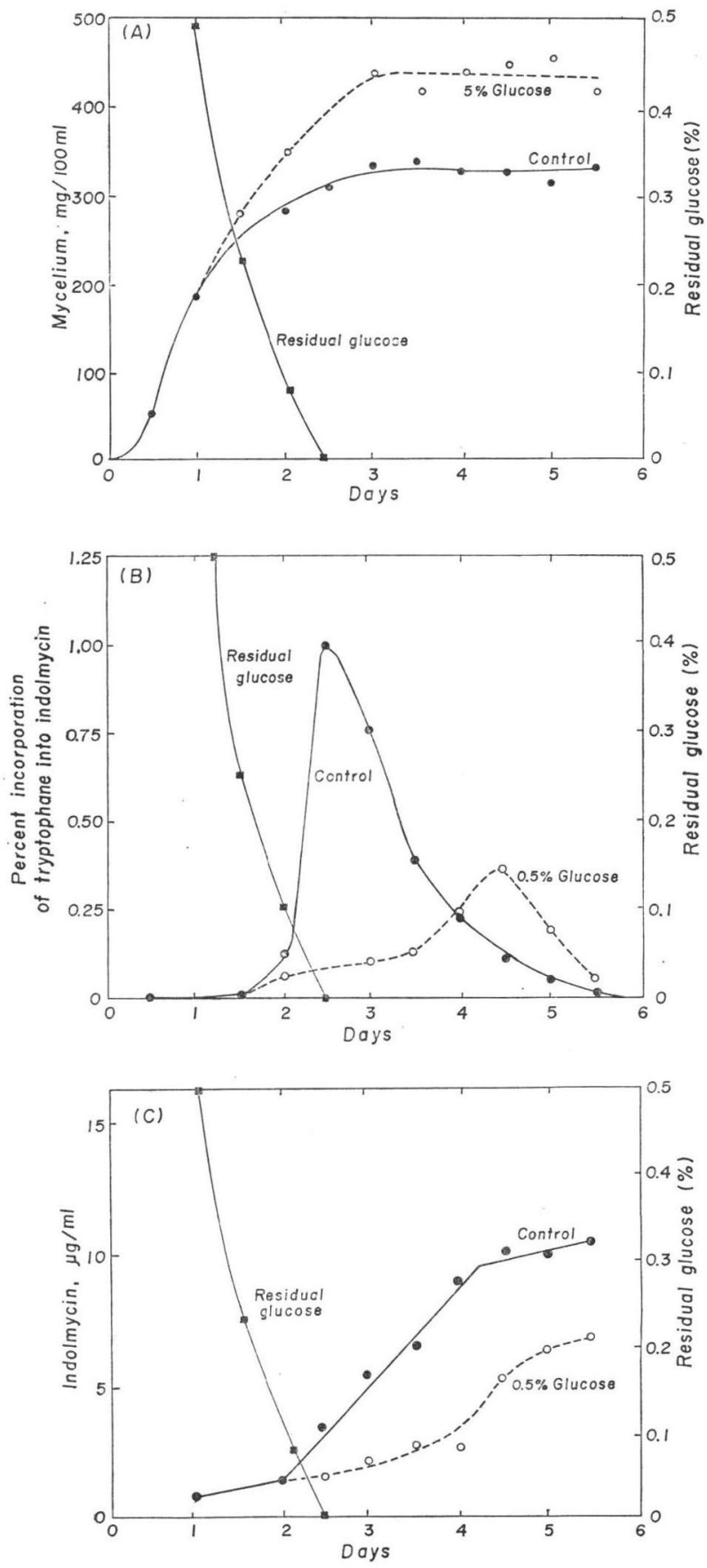
into indolmycin and amount of indolmycin produced over the control cultures.

The effect of various carbon sources on indolmycin biosynthesis is shown in Table 1 . Of the various carbon compounds evaluated, it was found that glucose and mannose produced a decrease in indolmycin synthesis and percentage incorporation of tryptophan into indolmycin, whereas sucrose, fructose and galactose caused a stimulation. Lactose and glucosamine had no appreciable effect.

The results in Table 2 show a 50 -fold difference between the differential indolmycin synthesized at $0.005 \%$ glucose and that at $0.5 \%$ glucose. Other than at a concentration of $0.005 \%$ there appears to be an inverse relationship between the weight of mycelium produced and the amount of indolmycin synthesized. The effect at $0.005 \%$ glucose is atypical but is nevertheless reproducible.

Examination of the effect of carbon sources other than glucose reveals that whereas mannose, sucrose, lactose, galactose and glucosamine produce lower differential indolmycin synthesis values than the control, fructose produces an increase in this value.

Of the compounds examined only mannose and galactose were found to have appreciable amounts of contaminating glucose $(\mathrm{Ta}$ ble 3).
Fig. 2. Effect of glucose $(0.5 \%)$ on the incorporation of DL-[alanine-3-14 C]tryptophan into indolmycin.

Streptomyces griseus cultures ( 33 hours old) were pooled, and DL-[alanine-3-314 $\mathrm{C}$ ] tryptophan was added. After dividing into two equal parts, glucose $(0.5 \%)$ was added to the test flask and both flasks allowed to incubate for 24 hours. At various times, aliquots were taken from both flasks and the percentage incorporation of tryptophan into indolmycin determined.

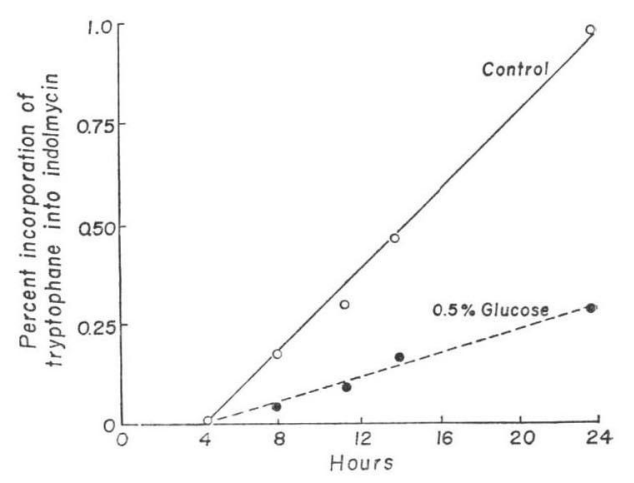

Fig. 3. Effect of varying concentrations of glucose on growth, percent incorporation of DL-[alanine-3-14 C]tryptophan into indolmycin and indolmycin production.

Streptomyces griseus cultures ( 33 hours old) were pooled and DL-[alanine-3- $\left.{ }^{14} \mathrm{C}\right]$ tryptophan $(0.05 \mu \mathrm{Ci} / 0.1 \mu$ moles per $\mathrm{ml})$ added. After dividing into equal fractions, various concentrations of glucose were added. The flasks were replaced on the shaker and allowed to incubate for a further 24 hours, at which time they were harvested and the various parameters determined for each culture.

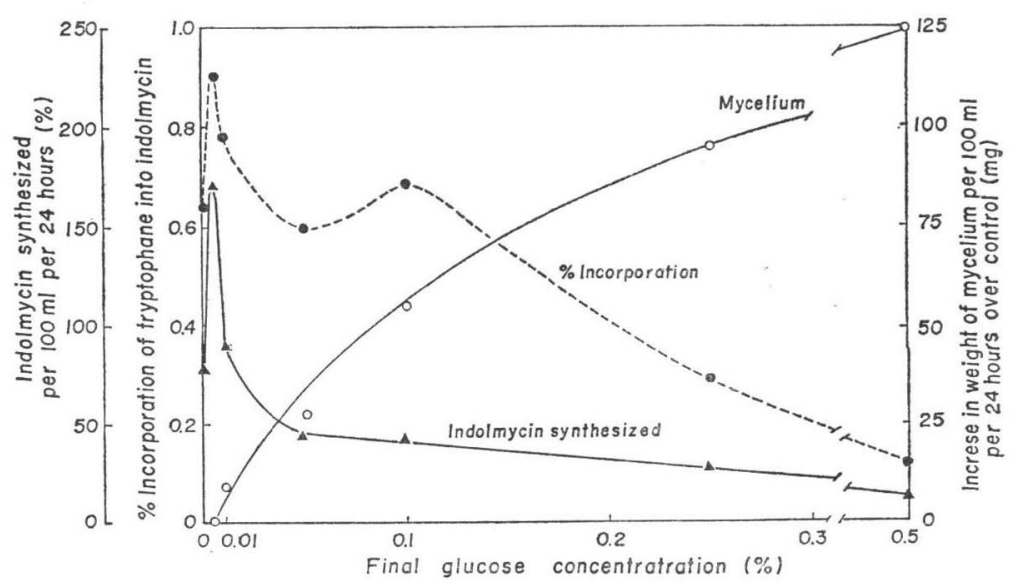

Discussion

Catabolite repression has been widely studied and documented in primary metabolism ${ }^{17,18}$. 
Table 1. Influence of various carbon compounds on indolmycin synthesis and incorporation of DL-tryptophan- $\left(3-{ }^{14} \mathrm{C}\right)$ into indolmycin by Streptomyces griseus

Thirty-three-hour cultures of Streptomyces griseus were pooled, and DL-[alanine-3-14C] tryptophan $(0.5 \mu \mathrm{Ci}$ per $0.1 \mu \mathrm{mole}$ per $\mathrm{ml})$ added. After dividing into equal fractions various compounds at $0.5 \%$ were added. The flasks were replaced on the shaker and allowed to incubate for a further 24 hours, at which time they were harvested and the percent incorporation of tryptophan into indolmycin and amount of indolmycin produced were determined.

\begin{tabular}{|c|c|c|c|c|c|}
\hline $\begin{array}{l}\text { Time } \\
\text { (hrs.) }\end{array}$ & $\begin{array}{c}\text { Compound } \\
(0.5 \%)\end{array}$ & $\begin{array}{l}\text { Indolmycin } \\
\text { synthesized } \\
(\mu \mathrm{g}) / 100 \mathrm{ml}\end{array}$ & $\begin{array}{l}\text { Increase or } \\
\text { decrease of } \\
\text { indolmycin } \\
\text { over control }\end{array}$ & $\begin{array}{l}\% \\
\text { Incorp. of } \\
\text { tryptophan } \\
\text { into indolmycin }\end{array}$ & $\begin{array}{c}\text { Increase or } \\
\text { decrease of } \\
\text { incorp. over } \\
\text { control }\end{array}$ \\
\hline 33 & Control & 48 & - & - & - \\
\hline 57 & Control & 127 & - & 0.64 & - \\
\hline 57 & Glucose & 57 & -88 & 0.12 & -88 \\
\hline 57 & $\mathrm{D}(+)$-Mannose & 93 & -44 & 0.33 & -47 \\
\hline 57 & Sucrose & 153 & +35 & 0.83 & +30 \\
\hline 57 & D-Fructose & 245 & +150 & 1.28 & +100 \\
\hline 57 & $\alpha$-Lactose & 140 & +15 & 0.69 & +8 \\
\hline 57 & Galactose & 150 & +30 & 0.86 & +34 \\
\hline 57 & Glucosamine & 137 & +12 & 0.61 & -5 \\
\hline
\end{tabular}

Table 2. The effect of various concentrations of glucose and different sugars on the amount of indolmycin synthesized per increase in dry weight of mycelium

Thirty-three hour cultures of Streptomyces griseus were pooled. After dividing into equal fractions, the sugars were added. The flasks were replaced on the shaker and allowed to incubate for a further 24 hours, at which time the flasks were harvested and the weight of mycelium and amount of indolmycin produced determined.

\begin{tabular}{|c|c|c|c|c|}
\hline \multirow[b]{2}{*}{ Carbon compound } & \multirow{2}{*}{$\begin{array}{l}\text { Conc. } \\
(\%)\end{array}$} & \multicolumn{2}{|c|}{ Increase after 24 -hour incubation } & \multirow{2}{*}{$\begin{array}{c}\text { Differential indolmycin synthesis } \\
\text { during } 24 \text { hours } \\
\frac{\Delta \mu g \text { Indolmycin }}{\Delta \mathrm{mg} \text { Mycelium }} \times 100\end{array}$} \\
\hline & & $\begin{array}{c}\text { Indolmycin } \\
\mu \mathrm{g} / 100 \mathrm{ml}\end{array}$ & $\begin{array}{l}\text { Mycelium } \\
\mathrm{mg} / 100 \mathrm{ml}\end{array}$ & \\
\hline None & - & 80 & 85 & 94.3 \\
\hline Glucose & 0.005 & 173 & 85 & 203.0 \\
\hline Glucose & 0.01 & 90 & 95 & 94.7 \\
\hline Glucose & 0.05 & 45 & 113 & 39.8 \\
\hline Glucose & 0.10 & 42 & 140 & 30.0 \\
\hline Glucose & 0.25 & 25 & 180 & 13.9 \\
\hline Glucose & 0.50 & 9 & 210 & 4.3 \\
\hline $\mathrm{D}(+)$-Mannose & 0.50 & 45 & 115 & 39.2 \\
\hline Sucrose & 0.50 & 105 & 130 & 80.7 \\
\hline D-Fructose & 0.50 & 197 & 170 & 116.0 \\
\hline$\alpha$-Lactose & 0.50 & 92 & 128 & 72.0 \\
\hline Galactose & 0.50 & 102 & 143 & 71.0 \\
\hline Glucosamine & 0.50 & 89 & 213 & 41.8 \\
\hline
\end{tabular}

However, in addition to causing repression of enzymes involved in primary metabolism, glucose has been shown to repress the synthesis of certain enzymes concerned with antibiotic production. These latter findings have resulted from studies on the effect of glucose on $\alpha$-Dmannosidase $^{11)}$ and phenoxazinone synthase ${ }^{71}$ which are enzymes in the biosynthetic pathways to streptomycin and actinomycin respectively.

The long-term experiment in which glucose at $0.5 \%$ was added before the main onset of 
Table 3. The amount of contaminating glucose found in the mono and disaccharides used in this investigation

\begin{tabular}{l|c|c}
\hline \multicolumn{1}{c|}{ Compound } & $\begin{array}{c}\text { Contaminating } \\
\text { glucose found } \\
\%\end{array}$ & $\begin{array}{c}\text { Calculated conc. } \\
\text { of contaminat- } \\
\text { ing glucose } \\
\text { added to each } \\
\text { flask } \\
\%\end{array}$ \\
\hline D(+)-Mannose & 2.4 & 0.012 \\
Sucrose & $<0.001$ & 0.000 \\
D-Fructose & $<0.001$ & 0.000 \\
$\alpha$-Lactose & $<0.001$ & 0.000 \\
Galactose & 0.7 & 0.004 \\
Glucosamine & $<0.001$ & 0.000 \\
\hline
\end{tabular}

indolmycin production produced an appreciable decrease in the rate of synthesis of indolmycin and the percentage incorporation of tryptophan into indolmycin. This data suggests that even when all the added glucose is utilized at $2 \frac{1}{2}$ days, its metabolites, which cause the repression or inhibition, are still present and only disappear gradually over a period of about another 2 days. Hence indolmycin is clearly another example of an antibiotic fermentation in which glucose can exert catabolite inhibition. Whether this inhibition is due to repression of synthesis of enzymes involved in the biosynthetic pathway leading to indolmycin or alternatively if it is due to other factors is as yet not clear and will have to await further

investigations where the levels of enzymes involved in the biosynthesis of indolmycin are measured under different conditions.

Since the long-term experiment was both very time-consuming and liable to large variation from one flask to another, the subsequent experiments carried out were of short-term duration and involved using representative samples from pooled cultures. From the long-term experiment, it was predicted that the period of maximum rate of synthesis of enzymes involved in the indolmycin pathway would take place over a period of time a few hours before the main onset of indolmycin production. This time period would probably occur between 30 and 60 hours. It was postulated that this would be the time at which the production of indolmycin would be most sensitive to inhibition or stimulation.

As an evaluation of this system for further studies, a time course experiment over a 24-hour period was carried out to determine the effect of $0.5 \%$ glucose on the incorporation of tryptophan into indolmycin. Biological variation between the control and test flasks was minimized by pooling the cultures and then subsequently subdividing them before adding glucose to the test flask. Glucose at a final concentration of $0.5 \%$ produced a $70 \sim 75 \%$ decrease in the percentage incorporation of tryptophan into indolmycin. The four-hour lag period before incorporation of exogenously added tryptophan into indolmycin was unexpected and whether this is due to a corresponding lag in uptake of tryptophan into the cells or due to existence of the more than one intracellular pool of tryptophan is not known.

The short-term experiments carried out on 33 hours old cultures showed that concentrations of glucose between $0.05 \%$ and $0.5 \%$ produced an inhibition of indolmycin production and incorporation of tryptophan into indolmycin. However, concentrations of $0.005 \%$ and $0.01 \%$ glucose produced a stimulation of indolmycin production and percentage incorporation of tryptophan into indolmycin. A similar dualistic effect of glucose on mannosidase an enzyme involved in streptomycin production has been shown previously ${ }^{12)}$. In addition, it has been reported in other organisms for several enzymes ${ }^{19 \sim 21}$. One possible explanation for this dualistic effect of glucose is that at low levels glucose acts as an energy source for enzyme synthesis but at higher concentrations glucose produces catabolite repression.

The fall in differential indolmycin synthesis between $0.01 \%$ and $0.5 \%$ glucose (Table 2) is due to an inverse relationship between growth and antibiotic production. An analogous effect has been previously shown by KATZ and co-workers but with respect to different carbon sources on actinomycin formation.

The different effects of various carbon sources other than glucose added at $0.5 \%$ is not so readily interpreted. Mannose produced inhibition of indolmycin formation which is in agreement with the findings of KATz and co-workers on actinomycin formation ${ }^{71}$. Mannose contains a small amount of contaminating glucose which may contribute to the inhibition of 
indolmycin production. Galactose contrary to the findings of KATZ and co-workers produced stimulation of antibiotic production; however, if the amount of contaminating glucose present in galactose is taken into consideration this stimulation can be accounted for as follows: The amount of contaminating glucose in galactose present falls within the range which causes stimulation of indolmycin production and therefore, could be responsible for this effect. The stimulation of indolmycin production by fructose and sucrose cannot be explained in a similar manner since these compounds contained negligible amounts of glucose. Since both these compouuds are metabolized (as indicated by the increase in weight of mycelium over and above the control culture), glucose would be released. It is suggested that the stimulatory effect of these compounds is therefore due to the slow release of glucose to produce a constant but low level of glucose (i.e. less than $0.01 \%$ ), which would produce stimulation of indolmycin production. Glucosamine and lactose although metabolized did not produce any appreciable effect on indolmycin formation.

\section{Acknowledgments}

We wish to thank EDWARD KATz for helpful advice. We would also like to thank the Pharmacy Classes of 1973 and 1974 who contributed to ground work upon which some of these experiments were based.

\section{References}

1) Routien, J. B.: Identity of streptomycete producing antibiotic. J. Bact. 91: 1663, 1966

2) Marsh, W.S.; A. L. Garretson \& E. M. Wesel: A, b, and x antibiotics produced by a strain of Streptomyces albus. Antibiot. \& Chemother. 10: 316 320, 1960

3) Preobrazhenskaya, M. N.; E. G. Balashova, K. F. Turchin, E. N. Padeiskaya, N. V. Uvarova, G. N. Pershin \& N. N. Suvorov: Total synthesis of antibiotic indolmycin and its stereoisomers. Tetrahedron 24: 6131 6143, 1968

4) RAO, K. V.: A new antibiotic. Antibiot. \& Chemother. 10: 312 316, 1960

5) Hornemann, U.; L. H. Hurley, M. K. Speedie \& H. G. Floss: The biosynthesis of indolmycin. J. Amer. Chem. Soc. 93: 3028 3035, 1971

6) Demain, A.L.: Regulatory mechanisms and the industrial production of microbial metabolites. Lloydia (Cincinnati) 31: 395 418, 1968

7) Gallo, M. \& E. Katz: Regulation of secondary metabolite biosynthesis: Catabolite repression of phenoxazinone synthase and actinomycin formation by glucose. J. Bact. 109: 659 667, 1972

8) Johnson, M. J.: Recent advances in penicillin fermentation. Bull. World Health Organ. 6: 99 121,1952

9) Kimura, A.: Biochemical studies on Streptomyces sioyaensis. I. Formation of siomycin by the resting cell system of Streptomyces sioyaensis. Agr. Biol. Chem. 31: 837 844, 1967

10) Kimura, A.: Biochemical studies on Streptomyces sioyaensis. II. Mechanism of the inhibitory affect of glucose on siomycin formation. Agr. Biol. Chem. 31: 845 852, 1967

11) Demain, A. L. \& E. Inamine: Biochemistry and regulation of streptomycin and mannosidostreptomycinase (alpha- $d$-mannosidase) formation. Bacteriol. Rev. 34: 1 19, 1970

12) Inamine, E.; B. D. Lago \& A. L. Demain: in "Fermentation Advances"' (D. Perlman, ed.), pp. 199 221, Academic Press, Inc. New York, 1969

13) Marshall, R.; B. Redfield, E. Katz \& E. Weissbach: Changes in phenoxazinone synthetase activity during the growth cycle of Streptomyces antibioticus. Arch. Biochem. Biophys. 123: 317 323, 1968

14) Kirsch, E. J. \& J. D. Korshalla: Influence of biological methylation on the biosynthes is of mitomycin A. J. Bact. 87: 247 255, 1964

15) Sмiтh, M. I.: A quantitative colorimetric reaction for the ergot alkaloids and its application in the chemical standardization of ergot preparations. U.S. Publ. Hlth. Rep. 45: 1466 1481, 1950

16) Worthington Biochemical Corporation. Manuel. Worthington Biochemical Corp., Freehold, N.J.

17) Paigen, K. \& B. Williams: Catabolite repression and other control mechanisms in carbohydrate utilization: in "Advances in Microbial Physiology" (A. Rose, ed.), Vol. 4, pp. 251 324, Academic Press, Inc. New York, 1970 
18) Pastan, I. \& R. Perlman: Cyclic adenosine monophosphate in bacteria. Science 169: 333 344, 1970

19) Durham, N. N. \& D. L. McPhereson: Influence of extraneous carbon sources on biosynthesis de novo of bacterial enzymes. J. Bact. 80: 7 13, 1960

20) MacQuillan, H. M.; S. Winderman \& H. O. Halvorson: The control of enzyme synthesis by glucose and the repressor hypothesis. Biochem. Biophys. Res. Commun. 3: 77 80, 1960

21) WIJK, R. VAN: Alpha-glucosidase synthesis, respiratory enzymes and catabolite repression in yeast. II. The effects of glucose on inducible and on constitutive alpha-glucosidase synthesis in whole yeast cells. Proc. Koninklijke Nederlandse Akad. van Wetenschappen. 71: 72 79, 1968 